\title{
Fault plane solutions of the January 26th, 2001 Bhuj earthquake sequence
}

\author{
Reena De ${ }^{1}, \mathrm{~S}$ G GaOnkaR ${ }^{2}$, B V SRirama ${ }^{2}$, Sagina Ram ${ }^{3}$ and J R Kayal ${ }^{4 *}$ \\ ${ }^{1}$ Geological Survey of India, Eastern Region, Salt Lake, Calcutta 700 091, India. \\ ${ }^{2}$ Geological Survey of India, Central Region, Nagpur 440 006, India. \\ ${ }^{3}$ Geological Survey of India, Northern Region, Lucknow 226 024, India. \\ ${ }^{4}$ Geological Survey of India, 27, J. L. Nehru Road, Calcutta 700 016, India. \\ *e-mail: jr_kayal@hotmail.com
}

A 12-station temporary microearthquake network was established by the Geological Survey of India for aftershock monitoring of the January 26th, 2001 Bhuj earthquake $\left(M_{W}\right.$ 7.6) in the Kutch district of Gujarat state, western India. The epicentres of the aftershocks show two major trends: one in the NE direction and the other in the NW direction. Fault-plane solutions of the bestlocated and selected cluster of events that occurred along the NE trend, at a depth of $15-38 \mathrm{~km}$, show reverse faulting with a large left-lateral strike-slip motion, which are comparable with the main-shock solution. The NW trending upper crustal aftershocks at depth $<10 \mathrm{~km}$, on the other hand, show reverse faulting with right-lateral strike-slip motion, and the mid crustal and lower crustal aftershocks, at a depth of $15-38 \mathrm{~km}$, show pure reverse faulting as well as reverse faulting with right-lateral and left-lateral strike-slip motions; these solutions are not comparable with the main-shock solution. It is inferred that the intersection of two faults has been the source area for stress concentration to generate the main shock and the aftershocks.

\section{Introduction}

On January 26th 2001, a devastating earthquake in the Bhuj area of Gujarat state, hereafter called the Bhuj earthquake, rocked the entire country. Immediately after the earthquake, the Geological Survey of India (GSI) mobilised its geology and geophysics teams for the post-earthquake investigations. The geology team carried out the macroseismic investigation, and the geophysics team carried out the aftershock investigation. About 3000 aftershocks $(M \geq 1.0)$ were recorded till April 15th 2001. From this large data-base we selected about 150 best located events $(M \geq 3.0)$ for determining fault-plane solutions, which shed light on the earthquake generating processes in the source area. Results of the fault-plane solutions are highlighted here.

\section{Main shock}

The Bhuj earthquake is the second largest earthquake $\left(M_{w} 7.6\right)$ that occurred in the Kutch paleorift zone in recorded history after the June 12th 1819 Kutch earthquake of magnitude $M_{w} 7.8$. Its epicentre lay about $100 \mathrm{~km}$ SE of the 1819 event, very near to the 1956 Anjar earthquake $\left(M_{s}\right.$ 6.1) in the same rift basin (figure 1). The earthquake caused wide-spread damage; the maximum intensity reached X on the MSK scale. The area spanned by the isoseismal of intensity VIII has been reported to be about 46,000 sq.km (Ravi Shanker and Pande 2001), compared to only about 500 sq.km for the 1993 Killari earthquake $\left(M_{b} 6.3\right)$, (GSI, 1996). The isoseismals VIII-X trend in the NE-SW direction, sub-parallel to the Kutch rift basin.

Keywords. Bhuj; mainshock; aftershocks; fault-plane solution; reverse faulting. 


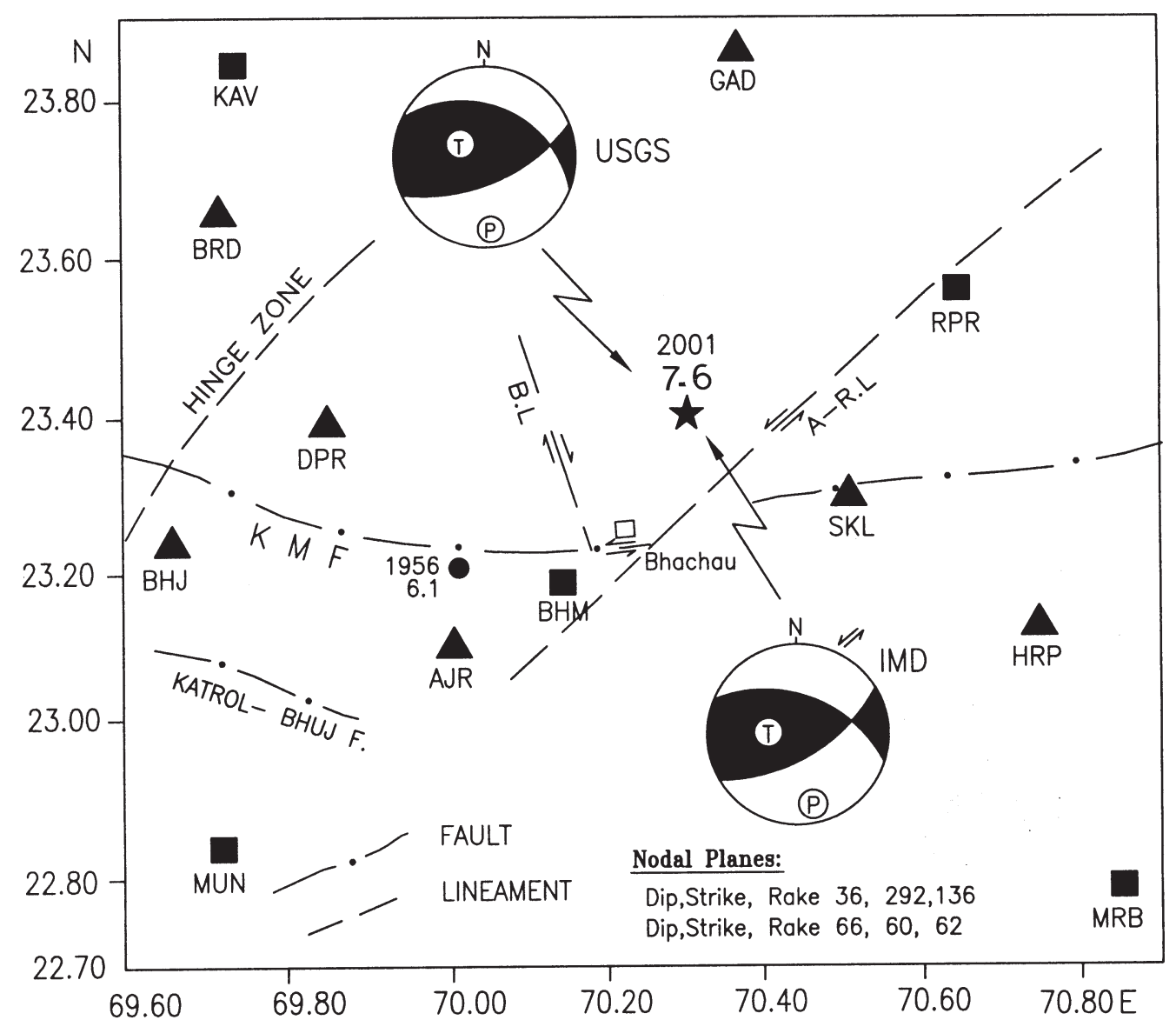

Figure 1. Map showing the GSI temporary network and major tectonic features in the main shock epicentre area; A-R.L: Anjar-Rapar lineament and B.L: Bhachau Lineament; the arrows indicate the ground movement (after Kayal et al 2003). The triangles indicate deployment of the eight analog (PS-2) instruments and the rectangles indicate the five digital (Reftek) instruments in the epicentre area. The RPR (Rapar) station is equipped with one analog and one digital instrument. The star indicates the epicentre of the main shock. Fault-plane solutions of the main shock (IMD and USGS) are shown with the usual notations.

Fault-plane solutions of the main shock were reported by several agencies; the USGS momenttensor solution and the IMD first-motion solution are compatible (figure 1). These solutions show reverse faulting with a strike-slip component, the south dipping ENE-WSW trending plane is the inferred fault-plane. Based on wave-form modelling, ERI (Japan) estimated the fault dimension of the order of $90 \mathrm{~km} \times 30 \mathrm{~km}$, and the maximum static displacement of $6.2 \mathrm{~m}$ at the hypocentre (Yagi and Kikuchi 2001). They also gave a faultplane solution which depicts a thrust-fault movement on a nearly $\mathrm{E}-\mathrm{W}$ trending fault plane.

\section{Aftershock investigation}

Immediately after the main shock, the GSI geophysics team established a 12-station network in the main-shock epicentre area. The network design and the major geological features are shown in figure 1 . This network recorded more than 3000 after- shocks of magnitude $\geq 1.0$ during the period January 29th to April 15th 2001. Details of the aftershock study are given by Kayal et al (2002). The epicentres of the best located 150 aftershocks show two trends, one in the NE and the other in the NW. These aftershocks are used for determining faultplane solutions.

\subsection{Fault-plane solutions}

Fault-plane solutions are always trivial, particularly with temporary network data. We have taken several steps to determine well constrained composite fault-plane solutions of the aftershocks in this study. We selected the best located clusters of aftershocks at different depth levels, and plotted the reliable $P$-wave first-motion data only. Lower hemisphere plot is made using the SEISAN's 'focmec' program (Havskov and Ottemoller 2000). Ten composite fault-plane solutions are thus obtained, these are illustrated below. 

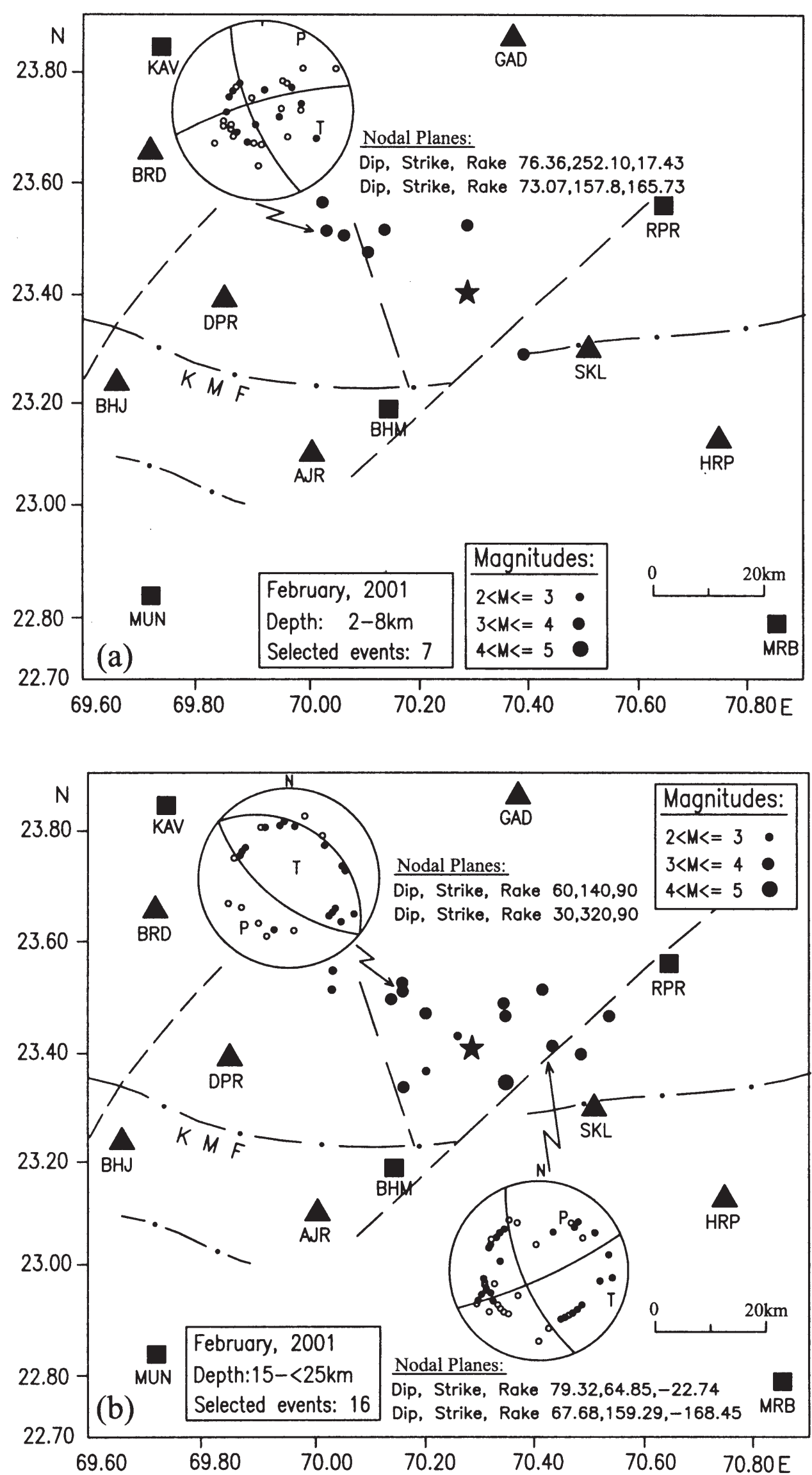

Figure 2. (Continued) 


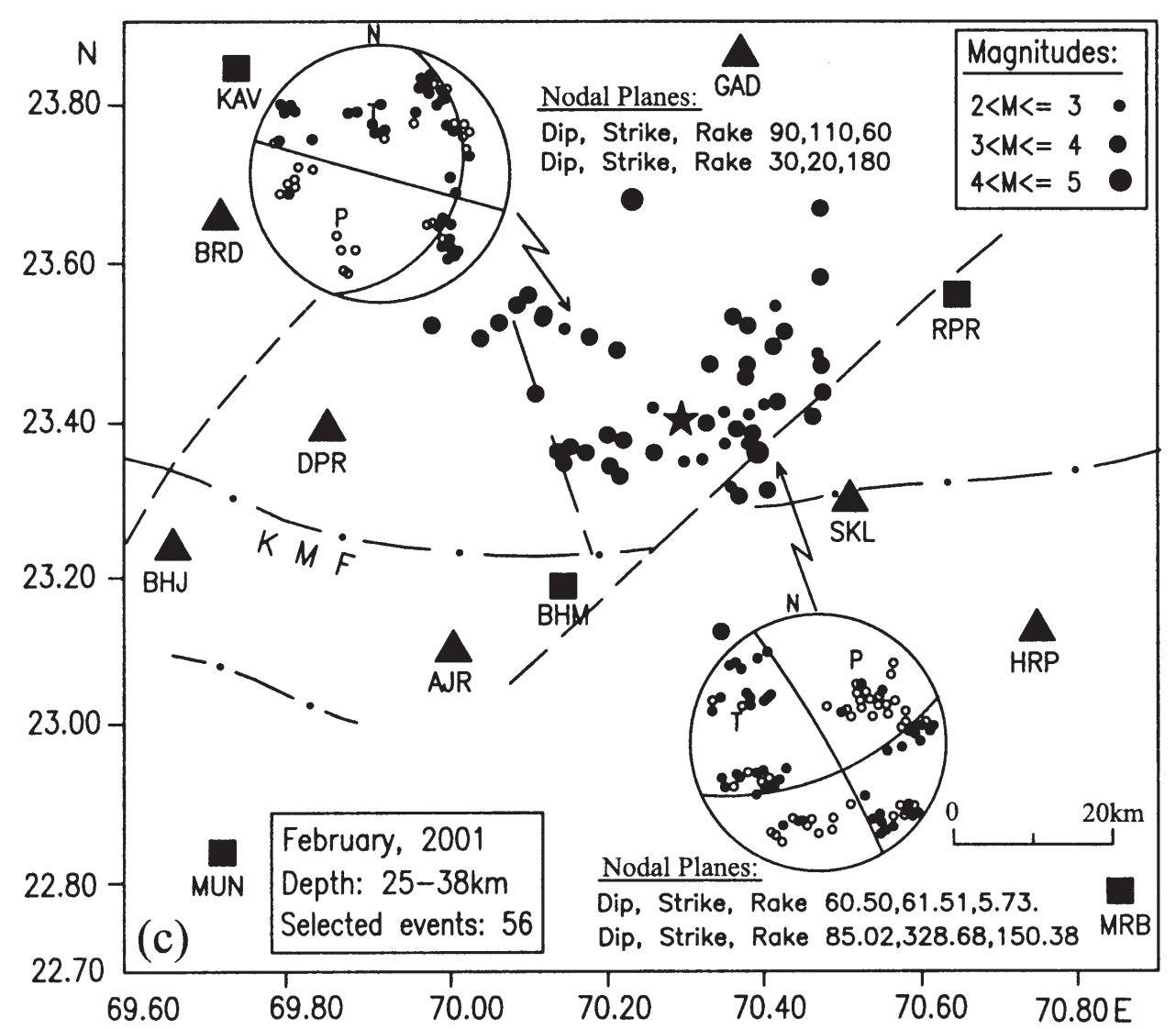

Figure 2(a-c). Epicentre maps showing the best located aftershocks recorded during February, 2001. (a) Composite fault-plane solution of the shallower aftershocks to the NW. (b) Composite fault-plane solutions of the mid-crustal aftershocks; one for the NW and the other for NE respectively. (c) Composite fault-plane solutions of the lower crustal aftershocks, one for the NW and the other for NE, respectively.

\section{1 .1 Depth $<10 \mathrm{~km}$}

In the upper crust, at $2-8 \mathrm{~km}$ depth, five best located events recorded during February 2001, which clustered to the NW (figure 2a), are used for a composite fault-plane solution. It shows a well constrained strike-slip solution. Right-lateral strike-slip motion is observed along the SW dipping or near vertical NW trending inferred fault plane (figure 2a). Another composite solution was obtained for a selected group of three events, at 2-8 km depth, recorded during March-April 15th 2001 (figure 3a). The solution is comparable with the above. It also shows right-lateral strike-slip motion along the NW trending inferred fault plane. The fault plane is nearly vertical, though a little rotation in dip is observed. No significant cluster of events was available in the NE direction for faultplane solution.

\subsubsection{Depth $15-<25 \mathrm{~km}$}

In the mid crust, at $15-<25 \mathrm{~km}$ depth, 16 best located events, recorded during February 2001, are selected for fault-plane solution (figure $2 \mathrm{~b}$ ). The epicentral map shows a cluster of events along both the two identified trends, NE and NW. Faultplane solution of the NW cluster of events shows pure reverse-faulting; the SW dipping NW trending nodal plane is the inferred fault plane. The cluster of events to the NE, on the other hand, shows strike-slip solution with a left-lateral strikeslip motion along the SE dipping NE trending inferred fault-plane.

Two composite solutions are also obtained for the selected events, at $15-<25 \mathrm{~km}$ depth, recorded during March-April, 2001 (figure 3b). The NW cluster of events shows a strike-slip solution. It shows right-lateral strike-slip along the SW dipping NW trending plane, and left-lateral strikeslip along the NE trending plane. The NE cluster of events, on the other hand, shows a left-lateral strike-slip solution; the SE dipping NE trending nodal plane is the inferred fault plane, which is consistent with the aftershock trend in the NE.

\subsubsection{Depth 25-38 km}

The maximum number of aftershocks occurred in the lower crust, at a depth range of $25-38 \mathrm{~km}$. The 

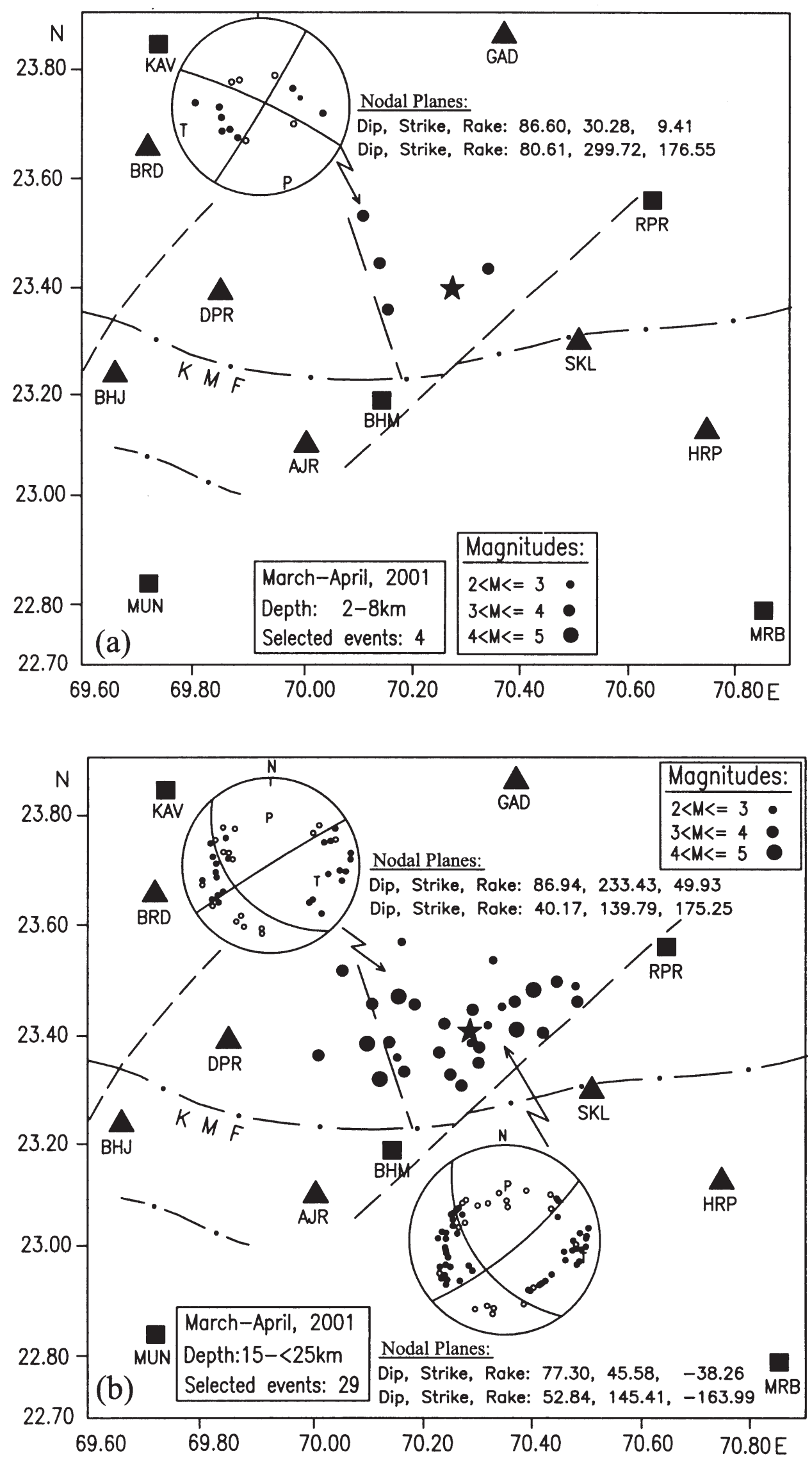

Figure 3. (Continued) 


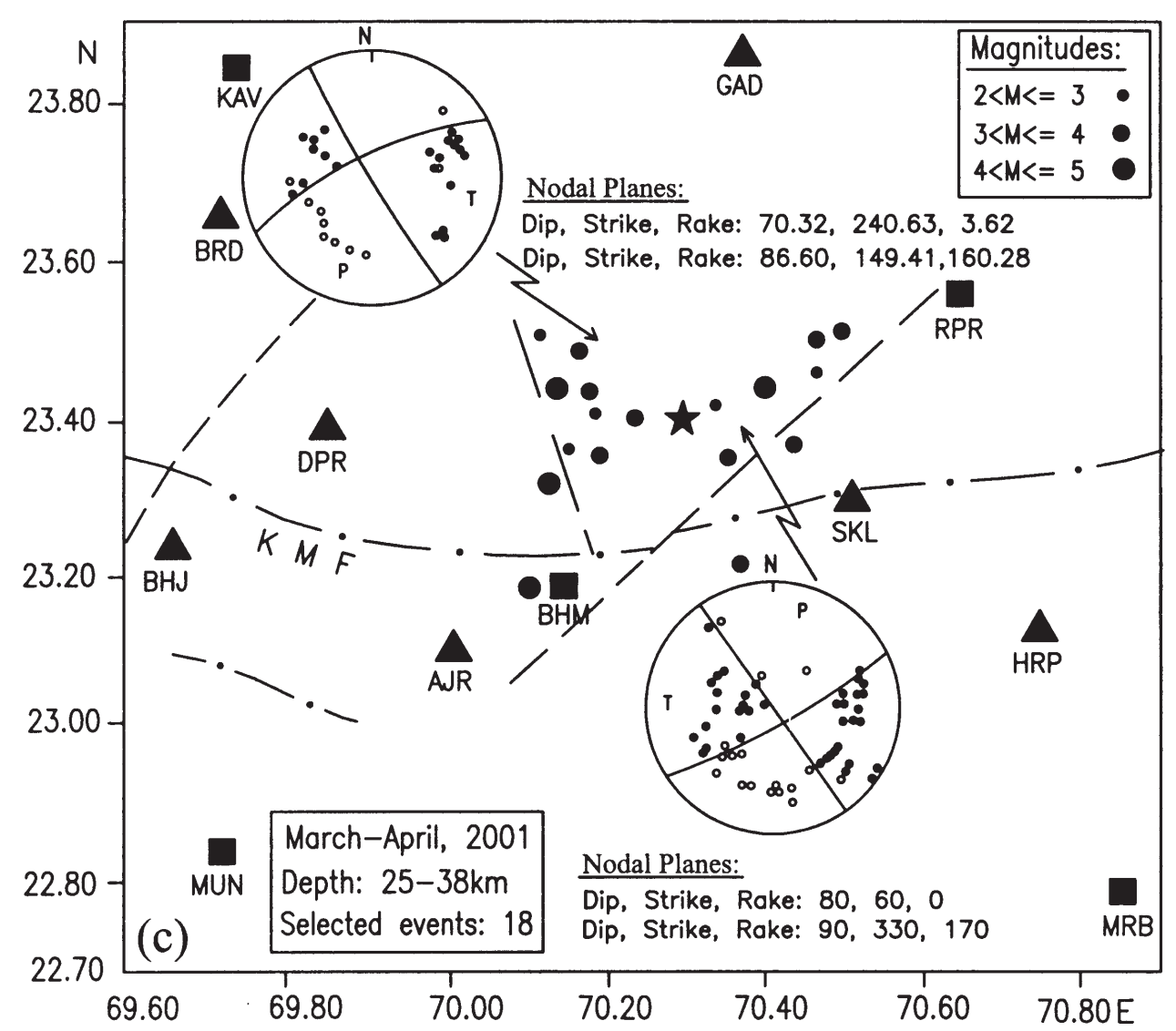

Figure 3(a-c). Epicentre maps of the best located aftershocks recorded during March-April, 2001. (a) Composite fault-plane solution of the shallower aftershocks to the NW. (b) Composite fault-plane solutions of the mid-crustal aftershocks, one for the NW and the other for NE respectively. (c) Composite fault-plane solutions of the lower crustal aftershocks, one for the NW and the other for the NE respectively.

56 best located events, recorded during February 2001, show the two identified trends, the NE trend is more prominent (figure 2c). The composite faultplane solution of 10 selected events along the NW trend shows a strike-slip faulting; the NW trending nodal plane is the preferred fault plane. The cluster of 22 events in the NE shows a strike-slip faulting with a large left-lateral strike-slip motion along the NE trending preferred fault plane.

Two composite solutions are obtained for the selected events, at $25-38 \mathrm{~km}$ depth, recorded during March-April, 2001 (figure 3c). The NW cluster of events shows strike-slip faulting with rightlateral strike-slip motion along the NW trending inferred fault plane. The NE cluster of events, on the other hand, shows strike-slip solution with a left-lateral motion along the NE trending inferred fault plane.

\section{Discussion}

The fault-plane solutions of the Bhuj aftershocks reveal several interesting observations. Detailed parameters of these solutions are given in figures 2 and 3.

The NW trending aftershocks at shallower depth $(2-8 \mathrm{~km})$ show right-lateral strike-slip faulting along the NW trending inferred near the vertical fault plane (figures $2 \mathrm{a}$ and $3 \mathrm{a}$ ). At the mid crustal depth $(15-<25 \mathrm{~km})$, the NW trending aftershocks recorded during February 2001 show dominantly reverse faulting (figure $2 \mathrm{~b}$ ). Later aftershocks recorded during March-April 2003, on the other hand, show strike-slip solution (figure $3 \mathrm{~b}$ ). At the lower crust, at $25-38 \mathrm{~km}$ depth, the solutions show predominantly strike-slip faulting with leftlateral and right-lateral strike-slip motions along the NW trending inferred fault (figures $2 \mathrm{c}$ and $3 \mathrm{c}$ ).

For the NE trending fault, we have no fault-plane solution for the shallower aftershocks at depth $<10 \mathrm{~km}$. The mid crustal and lower crustal NE trending aftershocks, at $15 \sim 38 \mathrm{~km}$ depth, show predominantly strike-slip faulting with left-lateral motion along the NE trending inferred fault plane (figures $2 \mathrm{~b}, \mathrm{c}$ and $3 \mathrm{~b}, \mathrm{c}$ ).

The fault plane solutions of the NE trending aftershocks are comparable with the main-shock 
solution. The fault-plane solutions of the NW trending aftershocks, on the other hand, are not comparable with the main-shock solution. It may be mentioned that the post-earthquake macroseismic investigation revealed left-lateral and rightlateral slip on the surface along the NE and NW trending lineaments/secondary ruptures respectively (Ravi Shanker and Pande 2001; Karanth et al 2001), (figure 1), which is conformable with the fault-plane solutions of the aftershocks.

The fault-plane solutions suggest that the mainshock was generated by reverse faulting at a depth of $25 \mathrm{~km}$, in the lower crust. The major rupture propagated along NE; the deeper aftershocks were mostly generated at the depth range of $15-38 \mathrm{~km}$ along this NE trending fault by reverse faulting with large left-lateral strike-slip motion, comparable with the main shock solution. A conjugate rupture propagated along NW; the shallower aftershocks (depth $<10 \mathrm{~km}$ ) along this NW trending fault, on the other hand, are generated by rightlateral strike-slip motion, and the mid crustal and lower crustal aftershocks, at 15-38 km depth, were generated predominantly by reverse faulting with left-lateral as well as right-lateral slip motions. All the fault-plane solutions, however, reveal a $\mathrm{N}-\mathrm{S}$ to NNE-SSW compressional stress in the region (figures 2 and 3 ).

The above observations suggest that the tectonic stress was concentrated at the fault intersections or at the 'fault ends' to generate the Bhuj earthquake sequence. Kayal et al (2002) inferred that a deep seated hidden fault at the base of the Kutch paleorift zone was activated by reverse faulting due to the compressional stress. The main shock generated the aftershocks mostly in the lower crust; the rupture propagated along two directions, $\mathrm{NE}$ and NW. These observations support 'fault interaction' model of the intraplate earthquakes (Kayal 2000; Talwani and Gangopadhyay 2001). The aftershock data clearly indicate that the deep seated (hidden?) fault(s) or juncture of the faults was the source area for the stress concentration at the base of the Paleo-rift zone to generate the main shock, and the asperity zones ruptured in the NE and NW directions to generate the aftershocks.

\section{Acknowledgement}

We are thankful to the Director General, GSI, for his kind support and encouragement to carry out this investigation. We are also thankful to our colleagues T R Goswami, G Chakraborty and P C Das, GSI (eastern region), A K Tiwari, Anwar Hakim, S K Singh, A Zaidi, Mehdi Hasan, GSI (northern region), S Samaddar, D V Punekar and G W Wahurwagh, GSI (central region), for their help in carrying out the field work. We thank the anonymous reviewers for their constructive comments.

\section{References}

GSI 1996 Killari Earthquake, 30 September 1993; Geol. Surv. of India sp. pub. $37282 \mathrm{pp}$

Havskov J and Ottemoller L 2000 SEISAN: The earthquake analysis software; Institute of Solid Earth Physics, Norway

Karanth R V, Sohoni P S, Mathew G and Khadikar A S 2001 Geological observations of the 26 January, 2001, Bhuj earthquake; J. Geol. Soc. India 58 193-202

Kayal J R 2000 Seismotectonics of the two recent SCR earthquakes in central India; J. Geol. Soc. India 55 123138

Kayal J R, De Reena, Sagina Ram, Srirama B V and Gaonkar S G 2002 Aftershocks of the January 26, 2001 Bhuj earthquake in western India; J. Geol. Soc. India 59 359-417

Ravi Shanker and Pande P 2001 Geoseismological studies of Kutch (Bhuj) earthquake of 26 January 2001; J. Geol. Soc. India $\mathbf{5 8} 203-208$

Talwani P and Gangopadhyay A 2001 Tectonic framework of the Kachchh earthquake of January 26, 2001; Seism. Res. Lett. 72 336-345

Yagi Y and Kikuchi M 2001 Western India Earthquake, website: http://www.eic.eriu-tokyo.ac.jp 